\title{
Criterios para la presentación y publicación de originales
}

\section{CONDICIONES DE PRESENTACIÓN PARA SU PUBLICACIÓN EN LA REVISTA}

- Los autores deberán enviar un archivo de cada original a la dirección de correo electrónico de la Secretaría de la revista.

- Los trabajos pueden ser enviados en español o en inglés. La edición en formato impreso será siempre en español y la edición en formato electrónico puede incluir la versión en inglés.

- Los trabajos que no se ajusten a los criterios formales exigidos serán devueltos a su autor.

\section{EVALUACIÓN Y ACEPTACIÓN DE ORIGINALES}

- El Consejo de Redacción remitirá al autor acuse de recibo de su trabajo y le informará si el trabajo ha sido admitido al proceso de evaluación, o bien de su rechazo por no cumplir los criterios formales o editoriales.

- Todos los trabajos que cumplan con los criterios formales y editoriales serán sometidos a un proceso de informe de dos evaluadores anónimos. Si existe contradicción entre los informes de los dos evaluadores se procederá a una tercera evaluación que se considerará definitiva.

- Los artículos no deben incluir expresiones que hagan referencia a la identidad del autor o autores dentro del texto.

- Bajo ninguna circunstancia se revelará la identidad de los evaluadores y sus informes motivados serán decisivos a la hora de que el Consejo de Redacción entienda procedente o no la publicación de los trabajos.

- En un plazo máximo de seis meses (que podrá ampliarse en circunstancias extraordinarias) el Consejo de Redacción remitirá al autor los resultados de la evaluación y le informará, en su caso, del tiempo de que dispone para realizar las correcciones pertinentes.

\section{CRITERIOS FORMALES DE PRESENTACIÓN DE ORIGINALES}

- Los artículos deben ser presentados exclusivamente en formato electrónico en tamaño DIN A4, a un espacio y medio atendiendo a márgenes normalizados a cada página. No se establece una extensión máxima, pero se sugiere que los trabajos considerados Estudios no excedan las 10.000 palabras, incluyendo notas y referencias bibliográficas y que los trabajos considerados Experiencias y Casos no excedan las 8.000 palabras, incluyendo notas y referencias bibliográficas.

- En archivo aparte el autor o autores deben enviar sus datos completos (institución, dirección postal, dirección electrónica y teléfono) y una breve reseña curricular (máximo 100 palabras) en la que incluyan grado académico, institución a la que pertenecen, líneas de investigación y principales publicaciones.

- Se recomienda que el título no exceda de 100 caracteres (incluyendo espacios).

- Cada trabajo debe acompañarse de un resumen de no más de 200 palabras, tanto en español como en inglés, y de una serie de palabras clave (máximo siete), preferentemente no incluidas en el título e igualmente en español y en inglés.

- Los gráficos, tablas, cuadros y otros dibujos e imágenes deberán integrarse dentro del texto e ir numeradas consecutivamente. Se hará referencia a las fuentes de procedencia y llevarán un título.

- Las citas en el texto deben hacerse entre paréntesis por autor y año, seguido de la página o páginas citadas (Lindblom, 1959: 79). Si se cita el trabajo de dos autores deberá incluirse el apellido de los dos unidos por la conjunción "y". Si se trata de tres o más autores, es suficiente citar el primer autor seguido de et al. Si se citan varios trabajos de un autor o grupo de autores de un mismo año, debe añadirse las letras a, b, c..., después del año, tanto en el texto como en el apartado final de "Referencias bibliográficas y documentales". 
- Las notas deben ir a pie de página y el autor debe asegurarse de que estas notas y las citas incluidas en el texto coincidan con los datos aportados en la bibliografía.

- Las referencias a prensa deberán incluir, cuando sea pertinente, el título del artículo que se cita entre comillas y, en todo caso, el nombre de la publicación en letra cursiva, la fecha de publicación y, si procede, la página o páginas. Por ejemplo:

The Economist, 27 de enero de 2008.

Toner, R., “New Deal Debate for a New Era”, The New York Times, 1 de agosto de 2007.

- Al final del texto debe incluirse, por orden alfabético, el listado completo de la bibliografía empleada. Se deben seguir los siguientes formatos:

Libro:

Meny, I. y Thoenig, J.C. (1992), Las políticas públicas. Barcelona: Ariel.

Weber, M. (1964 [1922]), Economía y sociedad. México D.F.: Fondo de Cultura Económica.

Trabajo en un libro colectivo:

Sabatier, P.A. y Jenkins-Smith, H.C. (1999), “The Advocacy Coalition Framework: An Assessment”, en P.A. Sabatier, ed., Theories of Policy Process. Boulder: Westview Press.

\section{Artículo:}

Goodsell, Ch. (2006), “A New Vision for Public Administration”, Public Administration Review, 66(5): $623-635$.

\section{Página web:}

Schmitter, P.C. (2004), "On Democracy in Europe and the Democratization of Europe", Documentos de Trabajo Política y Gestión 1. Madrid: Universidad Carlos III de Madrid. En línea: <http://www.uc3m.es/uc3m/dpto/ CPS/schmitter.pdf> (consulta: 20 diciembre 2008).

- Se recomienda evitar el uso de palabras en idioma distinto al español y de neologismos innecesarios. En caso de que su uso sea necesario por no existir traducción al español, se pondrá en letra cursiva.

- La primera vez que se utilicen siglas o acrónimos deberán escribirse entre paréntesis precedidos por el nombre completo.

Todas las referencias bibliográficas deberán estar acompañadas de su correspondiente número DOI, si lo tuviesen.

\section{DERECHOS Y OBLIGACIONES DE LOS AUTORES}

- Los autores ceden al INAP los derechos correspondientes al trabajo publicado en la revista, incluidos, con carácter exclusivo e ilimitado, los derechos a reproducir y distribuir el texto en cualquier forma o soporte (impresión, medios electrónicos o cualquier otra), además de los de traducción a cualquier otra lengua, sin perjuicio de las normas particulares o locales aplicables.

- El autor deberá adjuntar al original del texto que presente una declaración formal en la que haga constar que el contenido esencial del mismo no ha sido publicado ni se va a publicar en ninguna otra obra o revista mientras esté en proceso de evaluación en la revista DA, comprometiéndose en todo caso a comunicar de inmediato a la Dirección de la revista DA cualquier proyecto de publicación de dicho texto.

\section{SECRETARÍA DE LA REVISTA: “DOCUMENTACIÓN ADMINISTRATIVA”}

Instituto Nacional de Administración Pública

Centro de Publicaciones

C/ Atocha, 106. 28012 MADRID

Teléfono: (91) 27391 04. FAX: (91) 2739408

Correo electrónico: ana.uria@inap.es 